\title{
Identification of the Bioactive Compounds Hypotensive Effect in the Ethyl Acetate Extract of Eribroma oblongum (Malvaceae) Stem Bark
}

Tsague M. V. ${ }^{1,4}$, Fokunang Ntungwen C. ${ }^{8,6, *}$, Talla E. ${ }^{11}$, Djekilamber A. ${ }^{11}$, Tembe-Fokunang E. A. ${ }^{8}$, Ngo Lemba Tom E. ${ }^{5}$, Essomba C. ${ }^{2,9}$, Ntchapda F. ${ }^{3}$, Sokeng Dongmo S. ${ }^{3}$, Oben Enyong J. ${ }^{7}$, Ze Minkande J. ${ }^{1}$, Afane Ela A. ${ }^{1}$, Temdie Guemmogne R. J. ${ }^{3}$, Dimo T. ${ }^{2}$, Chi Fru G. ${ }^{10}$, Ngadjui Tchaleu B. ${ }^{9,10}$

\footnotetext{
${ }^{1}$ Department of Surgery and Specialties Faculty of Medicine and Biomedical Sciences, University of Yaounde I, Yaounde, Cameroon

${ }^{2}$ Department of Biology, Faculty of Sciences, University of Yaounde I, Yaounde, Cameroon

${ }^{3}$ Department of Biological Sciences, Faculty of Sciences, Ngaoundere, Ngaoundere, Cameroon

${ }^{4}$ Department of Biomedical Sciences, Faculty of Sciences, University of Ngaoundere, Ngaoundere, Cameroon

${ }^{5}$ Department of Biology, Higher Teachers' Training College, University of Yaoundé I, Yaounde, Cameroon

${ }^{6}$ Department of Sciences, Faculty of Science, University of Bamenda, Bamenda, Cameroon

${ }^{7}$ Department of Biochemistry, Faculty of Sciences, University of Yaounde I, Yaounde, Cameroon

${ }^{8}$ Department of Pharmaco-Toxicology and pharmacokinetics, Faculty of Medicine and Biomedical Sciences, University of Yaounde I, Yaounde, Cameroon

${ }^{9}$ Department of Pharmacognosy and Pharmaceutical Chemistry, Faculty of Medicine and Biomedical Sciences, University of Yaounde I, Yaounde, Cameroon

${ }^{10}$ Department of Organic Chemistry, Faculty of Sciences, University of Yaounde I, Yaounde, Cameroon

${ }^{11}$ Department of Chemistry, Faculty of Sciences, University of Ngaoundere, Ngaoundere, Cameroon
}

Email address:

charlesfokunang@yahoo.co.uk (Fokunang N. C.)

${ }^{*}$ Corresponding author

\section{To cite this article:}

Tsague M. V., Fokunang Ntungwen C., Talla E., Djekilamber A., Tembe-Fokunang E. A., Ngo Lemba Tom E., Essomba C., Ntchapda F., Sokeng Dongmo S., Oben Enyong J., Ze Minkande J., Afane Ela A., Temdie Guemmogne R. J., Dimo T., Chi Fru G., Ngadjui Tchaleu B. Identification of the Bioactive Compounds Hypotensive Effect in the Ethyl Acetate Extract of Eribroma oblongum (Malvaceae) Stem Bark. Journal of Diseases and Medicinal Plants. Vol. 2, No. 6, 2016, pp. 74-82. doi: 10.11648/j.jdmp.20160206.13

Received: October 6, 2016; Accepted: October 14, 2016; Published: November 21, 2016

\begin{abstract}
The stem bark of Eribroma oblongum (malvaceae) is used in traditional Cameroonian medicine to treat various metabolic illnesses including the management of hypertension but there is no scientific evidence to how relief is brought about. The present study was to evaluate the effect of the ethyl acetate extract of the dried stem bark of E. oblongum on arterial blood pressure and heart rate in normotensive rat (NTR) and their mechanisms of EAEO. The effects of ethyl acetate extract of Eribroma oblongum (EAEO; 10, 20, $30 \mathrm{mg} / \mathrm{kg}$; i.v) was tested on systolic blood pressure (SBP) and heart rate (HR) of normotensive rat. The mechanism of EAEO $(20 \mathrm{mg} / \mathrm{kg})$ was studied in the presence of atropine, yohimbine, propranolol, LNAME or reserpine. At the end of the experiment, SBP and HR were recorded. EAEO $(10-20 \mathrm{mg} / \mathrm{kg})$ induced a significant hypotensive effect of SBP. The hypotensive effects of EAEO $(20 \mathrm{mg} / \mathrm{kg})$ were inhibited by pre-treatment of rats with atropine, reserpine, yohimbine and L-NAME. At the end of this study the result demonstrates that the hypotensive as well as the antihypertensive effects of the ethyl acetate extract of the stem bark of Eribroma oblongum. Our data validate the use of the extract in traditional medicine against hypertension. The effect on blood pressure is, at least in part, due to a modulation of the orthosympathetic nervous system and to the improvement of the antioxidant status. Further studies are from now needed to study the toxicity of Eribroma oblongum.
\end{abstract}


Keywords: Eribroma oblongum, Betulinic Acid, Hypotensive Effect, Wistar Rats

\section{Introduction}

Previous study showed that the hydroethanolic extract of Eribroma oblongum possesses antihypertensive and antiatherogenic properties. The present work investigates the hypotensive effect and mechanisms of some compounds from the stem bark ethyl acetate extract of Eribroma oblongum in Wistar rats. The hypotensive activity of the ethyl acetate extract of the stem bark of Eribroma oblongum (Malvaceae) lead to the phytochemical study of this extract which established betulinic acid as the main hypotensive principle. The other compounds isolated: tridecyl 9hdroxylnonanoate and three others compounds showed few activities. The structure of isolates were established on the basis of NMR inspection, mass spectrometric data and by comparison with those previously reported in the literature. The hypotensive activity was carried out by intravenous injection of different concentration of the extract and natural products using a right carotid receptor attached to a recorder and computer, to monitor the arterial pressure changes of wistar rat.

Hypertension refers to an increase in arterial pressure [1]. It arises from peripheral resistance to blood flow due to increased vasoconstriction and therefore, excess pressure is needed to circulate blood at the normal rate. This has been attributed to the action of norepinephrine and other vasoconstricting hormones [2]. The prevalence in men and women is $18.7-23.8 \%$ and $12.7-18.8 \%$, respectively. In this developing country, the cost of modern drug therapy is prohibitive and as such, many patients resort to traditional herbal medicine for treatment [3]. Eribroma oblongum is a plant of the Malvaceae family common to the West African society, in the dense humid forest where it grows up to the diameter of $18.6 \mathrm{~mm}$ [4]. It is used as timber, for the making of floors, ceiling, and as wood for many other articles [5]. It is commercialised under the name Eyong okoko and Ohaa. In Cameroon, the bark of Eribroma oblongum is used for the treatment of cramps, stomach burns, painful menstruation and hypertension. The aim of this study was to evaluate the antihypertensive properties of the extract, fractions and compounds obtain from E. Oblongum with the objective of identifying the active principles. To the best of our knowledge, no pharmacological or phytochemical work has been reported from this plant, but previous works of the Malvaceae species led to the isolation of flavonoids, phenols, polyphenols, anthocyanins, tritepenoids and steroids [6], [7], [8]. These compounds have been shown to possess various pharmacological properties.

Plants have proven to be useful in curing diseases and provide an important source of medicine. Plants have great significance to the health of individuals. The medicinal value of these plants lies in some chemicals that produce a specific physiological action on the human body. These major bioactive compounds include saponins, phenols, reducing sugar, and terpenoids. Plants have served as important material for drug development. Plants are now playing an important role in many medicines like allopathic medicine, herbal medicine, homoeopathy and aromatherapy. However, during the last decade, an increase in the use of medicinal plants has been observed in developed countries [9]. Further some synthetic drugs have been suspected to cause undesirable side effects [10], [11]. Globally, herbal medicine is gaining popularity even in region with improved health care systems [12]. The medicinal properties and other properties of some plants have been recognized by various researches.

The aim of the present study was to evaluate the effect of the dried stem bark of fraction of ethyl acetate extract, pure bioactive compounds and their mechanism of action on arterial blood pressure and heart rate in normotensive rats (NTR).

\section{Material and Methods}

\subsection{Chemicals}

Urethane was obtained from Prolabo, France. Atropine sulphate, propranolol, yohimbine, reserpine and L-NAME (Nw- L-Nitro Arginine Methyl Ester) from Sigma Chemical, St Louis, MO, USA. Heparine was from Sanofi, France. The drugs were freshly prepared before the experiment. All drugs and the plant extract were dissolved in distilled water.

\subsection{Sample Collection and Preparation of the Pure Compound}

Fresh stem bark of Eribroma oblongum were collected at Eseka, centre province of Cameroon, in August 2013. The plant material was identified at the National Herbarium (HNC) of Yaoundé-Cameroon where a voucher specimen $\mathrm{N}^{\circ} 27489$ SRFCam has been deposited. The air-dried and powdered stem bark $(2.0 \mathrm{~kg})$ was macerated in hexane for $48 \mathrm{~h}$, the resulting extract was filtered, and the solvent removed on a rotary evaporator. This same procedure was repeated trice with hexane (Hex) before proceeding to Ethyl Acetate (EA) and then methanol $(\mathrm{MeOH})$. The Hex, EA and $\mathrm{MeOH}$ extracts were respectively $10.0 \mathrm{~g}, 110.0 \mathrm{~g}$ and 180.0 g. Hypotensive activity tests carried on the different extracts highlighted the EA extract as most active and so $90.0 \mathrm{~g}$ of the EA extract was subjected to repeated silica gel column chromatography using hexane (Hex), hexane-Ethyl Acetate (EA) and EA- Methanol (MeOH). 143 fractions of $275 \mathrm{~mL}$ each was collected, from which betulinic acid (Hex-EA: 7030, $43.35 \mathrm{mg}$ ), tridecyl 9-hydroxynonanoate (Hex-EA: 85-15, $54.25 \mathrm{mg}$ ), a fatty acid (Hex-EA: 90-10, $33.82 \mathrm{mg}$ ) were 
obtained after the solvent evaporated, washing with appropriate solvents and filtration.

\subsection{Phytochemical Screening}

Phytochemical screening was done as described by [13]. for evaluation of reducing sugars, saponins, flavonoids, tannins, phenols, lipids, steroids, terpenoids, cardiac glycosides, anthraquinones, alkaloids and triterpenes.

\subsection{Animal Studies}

Male albino Wistar rats of 12 weeks old weighting 180$250 \mathrm{~g}$ were used. The animals were maintained on a $12 \mathrm{~h}$ light/dark cycle, with free access to water and standard Laboratory diet. Normotensive rats (NTR) were used to evaluate hypotensive effect in the ethyl acetate extract and compounds on arterial blood pressure, heart rate and its mechanisms of action.

\subsection{Acute Effect of Eribroma Oblongum on Blood Pressure and Heart Rate of Normotensive Rats}

The rats were anaesthetized using an intraperitoneal injection of urethane $(1.5 \mathrm{~g} / \mathrm{kg})$. The trachea was exposed and cannulated to facilitate spontaneous respiration. The arterial blood pressure was measured from right carotid artery via an arterial cannula connected to a pressure transducer, coupled with a hemodynamic recorder Biopac Student Lab. (MP35) and computer. The animals were allowed to stabilize for at least $30 \mathrm{~min}$ before administration of any test substances [14]. The plant extract or drugs were injected via a cannula inserted into the left femoral vein. The dose of $10 \mathrm{mg} / \mathrm{kg}$ was used to investigate the hypotensive mechanism of E. oblongum. Atropine (1 $\mathrm{mg} / \mathrm{kg})$, yohimbine $(100 \mu \mathrm{g} / \mathrm{kg}), \quad \mathrm{Nw}-\mathrm{Nitro}-\mathrm{L}-$ arginine Methyl Ester (L-NAME, $5 \mathrm{mg} / \mathrm{kg}$ ) and propranolol $(30 \mu \mathrm{g} / \mathrm{kg})$ were injected $5 \mathrm{~min}$ before the plant extract. In another set of study, the extract was injected $5 \mathrm{~min}$ before L-NAME. Reserpine ( $5 \mathrm{mg} / \mathrm{kg}$ ) was given orally to NTR once a day and three days after, the extract $(10 \mathrm{mg} / \mathrm{kg})$ was injected to rats after anaesthesia. Blood pressure and heart rate were observed for $1 \mathrm{~h}$ after drug administration.

\subsection{Statistical Analysis}

All results are expressed as mean \pm standard error of mean (S.E.M.) and statistical analysis was performed using Graph Pad Instat Software. Data were analysed using one-way analysis of variance ANOVA followed by Tukey post hoc

\section{Results}

\subsection{Phytochemical Screening of Plant Materials}

Phytochemical analysis revealed the presence of reducing sugar, triterpene, terpenoids, flavonoids, phenols and saponins. Alkaloids, lipids, steroid cardiac glycosides, anthraquinones, and tannins were absent.
Table 1. Phytochemical constituents of ethyl acetate extract of Eribroma oblongum.

\begin{tabular}{ll}
\hline Constituents & Ethyl acetate \\
\hline Test for reducing sugars & ++ \\
Test for triterpenes & + \\
Test for terpenoids & + \\
Test for flavonoids & + \\
Test for saponins & +++ \\
Test for phenol & - \\
Test for anthraquinones & - \\
Test for cardiac glycosides & - \\
Test for tannins & - \\
Test for alkaloids & - \\
Test for lipid & - \\
Test for steroids & - \\
\hline
\end{tabular}

$(-)$ : absent; $(+)$ : present

\subsection{Identification of Compounds 1 and 2}

Phytochemical studies of the ethyl acetate extract from the stem bark E.oblongum yielded betulinic acid [15], Tridecyl 9-hydroxynonanoate.

Compound 1 was isolated as a white powder and determined to have a molecular formula $\mathrm{C}_{30} \mathrm{H}_{48} \mathrm{O}_{3}$ from its NMR data and ESI-MS which gave a pseudo-molecular ion peak at $\mathrm{m} / \mathrm{z}: 456.06$ (calcd $[\mathrm{M}]^{+}:$456.3623). This composition accounted for seven double bond equivalents. Compound 1 responded positively to the LiebermannBurchard test indicative of triterpenes. The structure of this compound was determined using its NMR data and by comparison with similar data in literature [15].

Betulinic acid: 3 $\beta$-hydroxylup-20(29)-en-28-oic acid

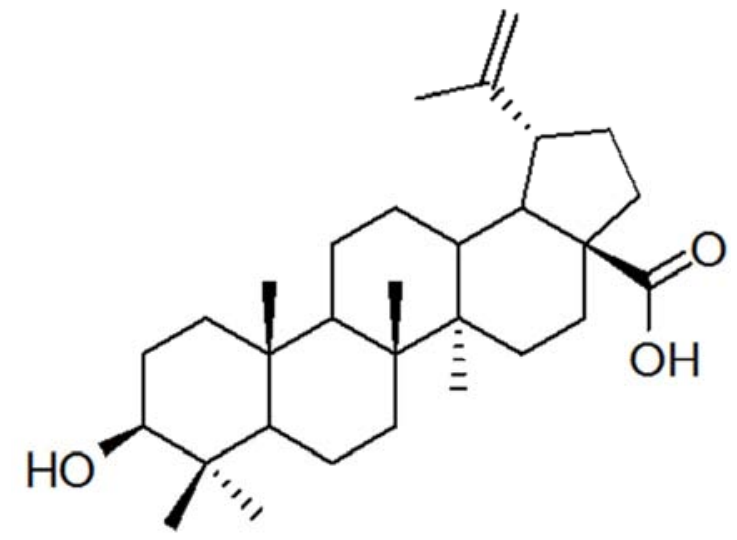

Figure 1. 33-hydroxylup-20(29)-en-28-oic acid.

White powder or colourless crystals in methanol, m.p. [280-282 $\left.{ }^{\circ} \mathrm{C}\right]$

ESI-MS: $\mathrm{m} / \mathrm{z} 456.06$ [calc. $\mathrm{C}_{30} \mathrm{H}_{48} \mathrm{O}_{3}$ : 456.3623]

${ }^{13} \mathrm{C}-\mathrm{NMR}\left(\mathrm{CDCl}_{3}, 75 \mathrm{MHz}\right)$ data: $38.7(\mathrm{C}-1), 27.4(\mathrm{C}-2)$, 79.0 (C-3), 38.9 (C-4), 55.4 (C-5), 18.4 (C-6), 34.4 (C-7), 40.7 (C-8), 50.7 (C-9), 37.2 (C-10), 20.9 (C-11), 25.5 (C12), 38.4 (C-13), 42.5 (C-14), 30.6 (C-15), 32.2 (C-16), 56.3 (C-17), 46.9 (C-18), 49.3 (C-19), 150.5 (C-20), 29.7 (C-21), 37.1 (C-22), 28.0 (C-23), 15.4 (C-24), 16.1 (C-25), 16.2 (C-26), 14.7 (C-27), 180.5 (C-28), 109.7 (C-29), 19.4 (C-30). 


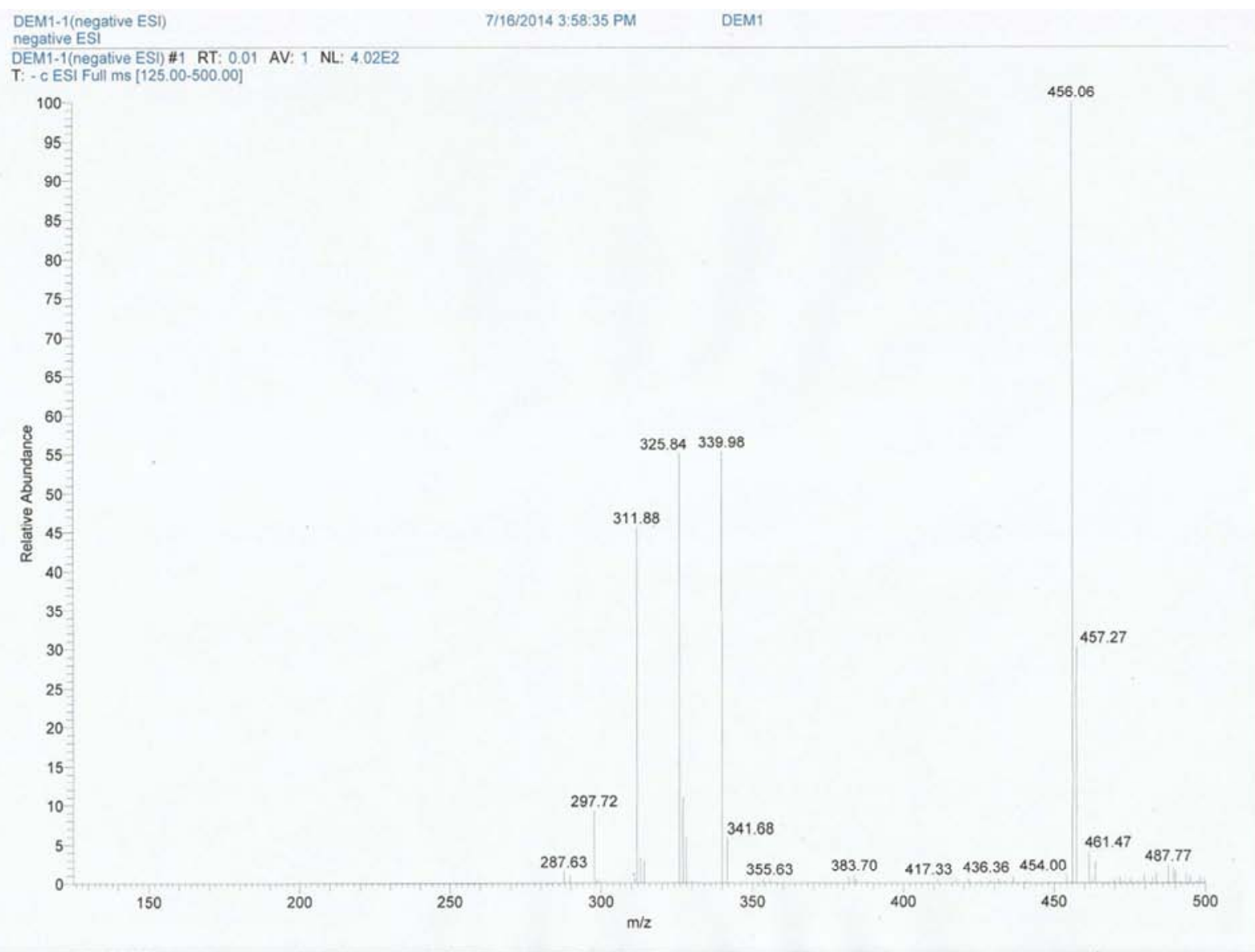

Figure 2. Mass Spectrum of compound.

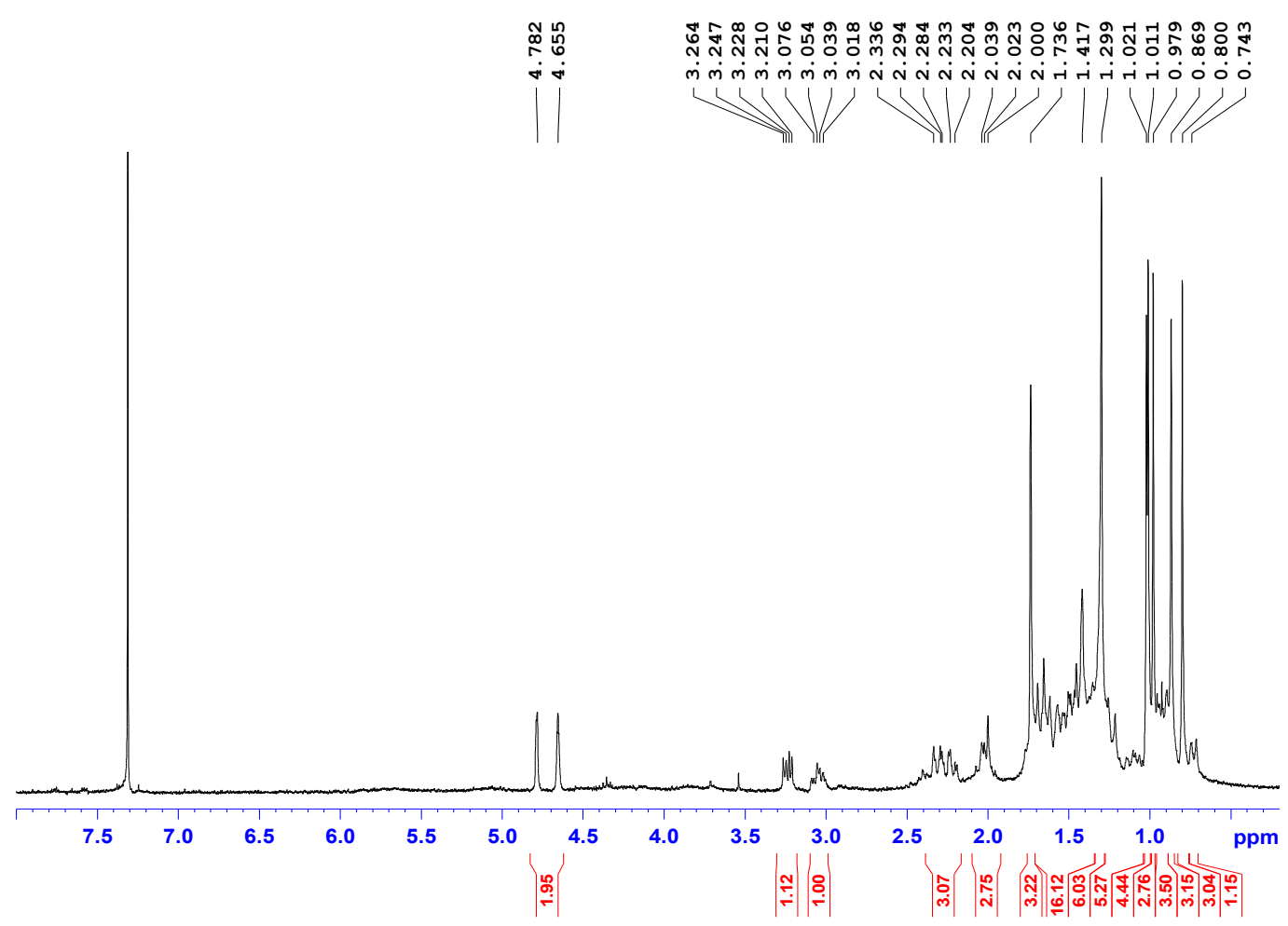

Figure 3. $R M N^{l} H$ Spectrum (500 MHz, MeOD) of compound. 


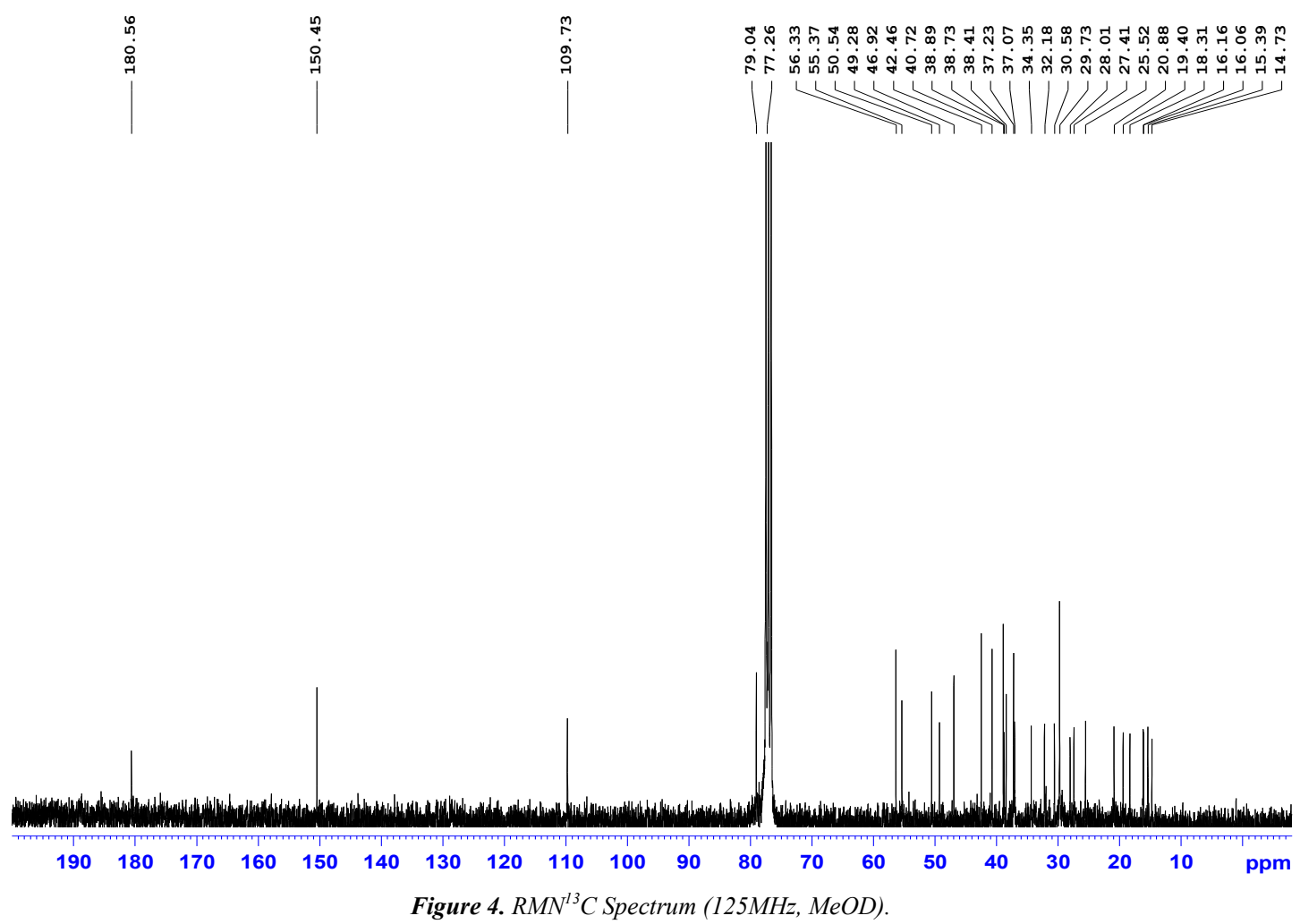

Compound 2 was obtained as a white powder which is soluble in chloroform. Its structure was proposed by use of its NMR data in conjunction with similar data found in the literature.

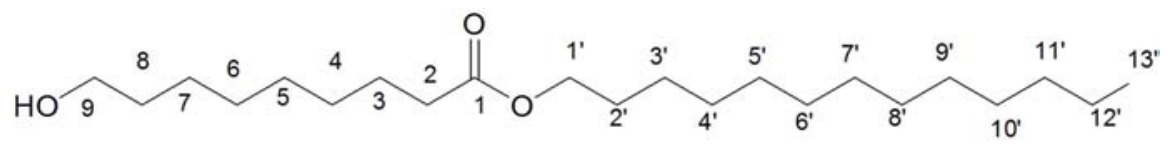

Figure 5. Chemical structure of Tridecyl 9-hydroxynonanoate.

White powder,

$\mathrm{C}_{22} \mathrm{H}_{44} \mathrm{O}_{3}$

${ }^{13}$ C-NMR data: 174.85 (C-1), 27.21- 31.52 (C-2 to C-8), 65.32 (C-9), 63.52 (C-1'), 27.21- 31.52 (C-2' to C-12'), 14.87 (C-13').

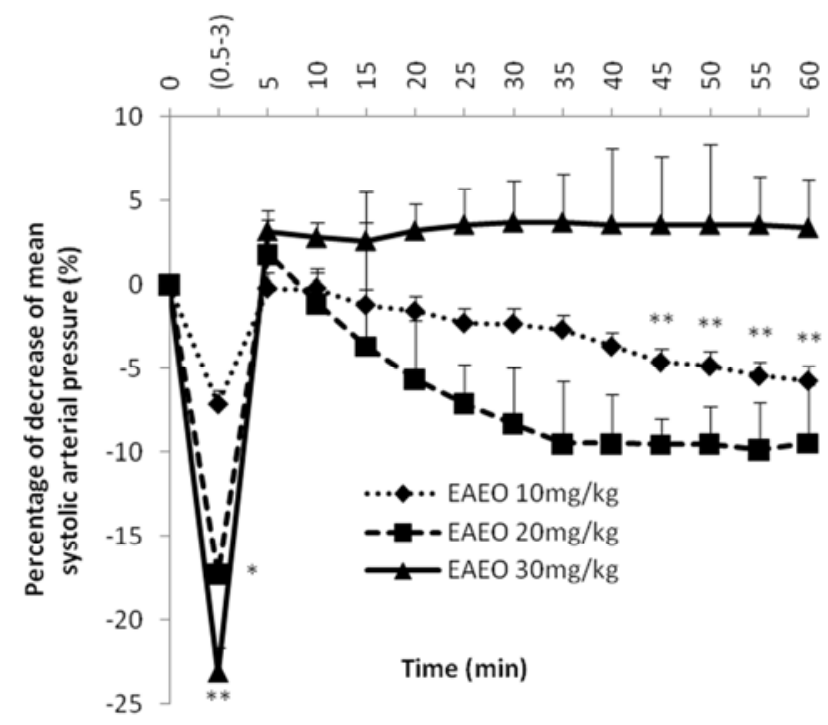

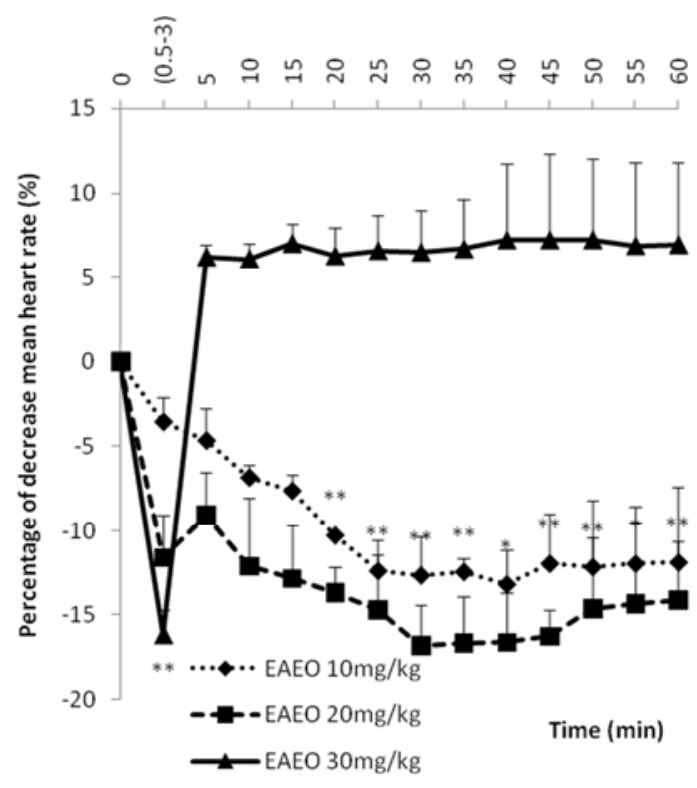

Figure 6. Changes on systolic arterial pressure (A) and heart rate (B) of anesthetized rats after intravenous administration of EAEO (Ethyl Acetate extract of Eribroma oblongum); $n=5$ each bar represents the means $\pm S E M$ of group; ${ }^{*} P<0.05,{ }^{* *} P<0.01$; significantly different compared to initial time $t_{0}$. 


\subsection{Effects of Acute Injection of Eribroma Oblongum on Blood Pressure and Heart Rate}

The injection of the extract of Eribroma oblongum in normotensive rats (NTR) resulted in a significant rapid reduction of systolic blood pressure (SBP). As shown in fig. 6 Eribroma oblongum reduced the SBP in NTR significantly by $17.29 \pm 0.5 \%(\mathrm{P}<0.05)$ and by $23.15 \pm 1.47 \%(\mathrm{P}<0.01)$ at the dose 20 and $30 \mathrm{mg} / \mathrm{kg}$ respectively. The first and rapid hypotensive response was followed by a transient increase of
SBP, after that SBP decrease progressively and significantly until the end of the observation period the PAS was at $5.76 \pm 0.86 \%(\mathrm{P}<0.01), 8.48 \pm 3.47 \%$ at the dose $10,20 \mathrm{mg} / \mathrm{kg}$ respectively and increase of $3.35 \pm 2.92 \%$ the dose $30 \mathrm{mg} / \mathrm{kg}$. The intravenous administration of the extract in NTR resulted in a significant $\mathrm{P}<0.01$ rapid reducing of heart rate (HR) by $16.14 \pm 1.46 \%$ at the dose $30 \mathrm{mg} / \mathrm{kg}$. The first and rapid decrease of HR response was followed by an increase of HR
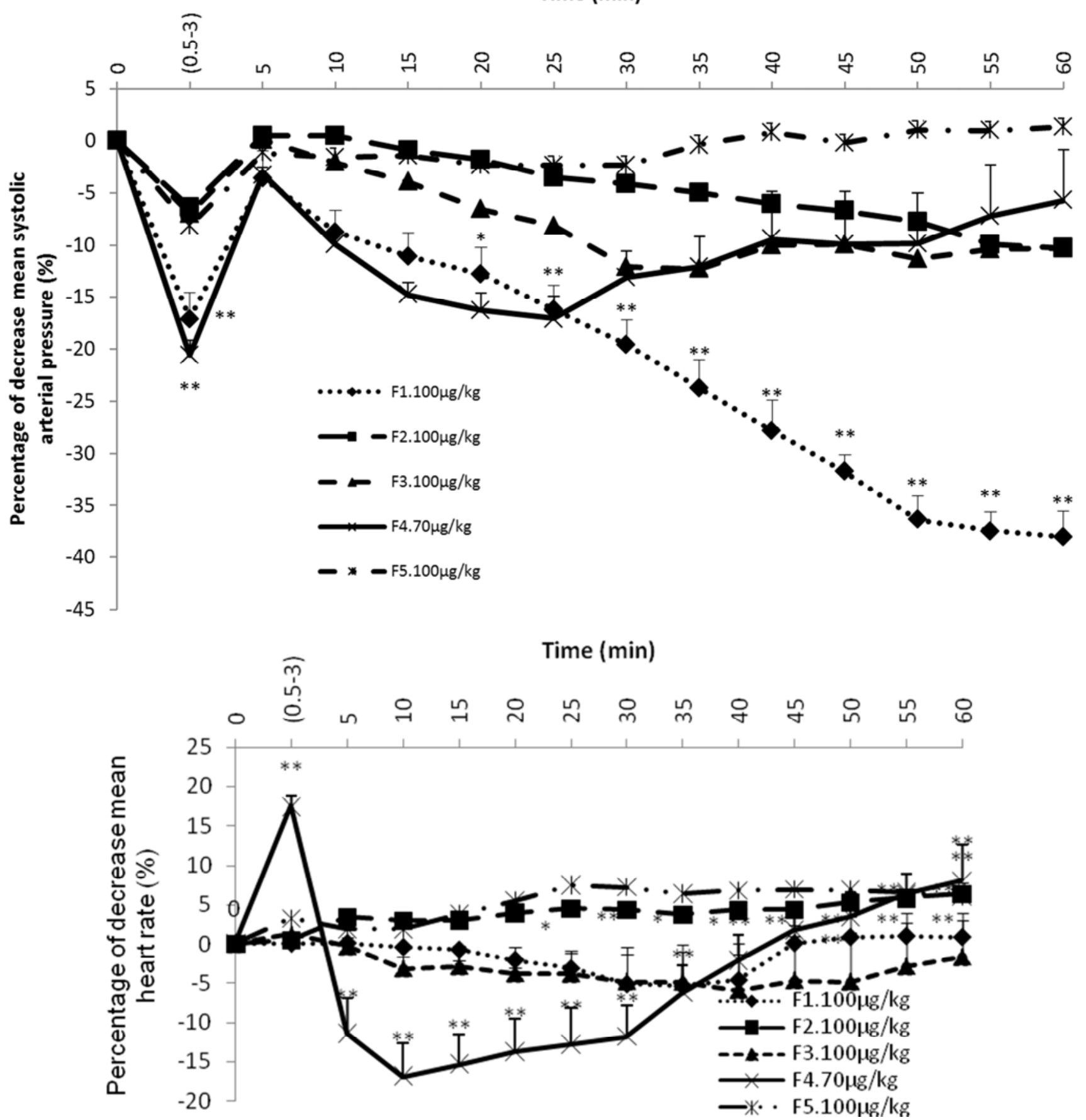

Figure 7. Changes on systolic arterial pressure $(A)$ and heart rate $(B)$ of anesthetized rats after intravenous administration of $F 1, F 2, F 3, F 4$ or F5 $(F=$ compound of ethyl acetate extract of Eribroma oblongum); $n=5$ each bar represents the means \pm SEM of group; ${ }^{*} P<0.05$, ${ }^{* *} P<0.01 ;$ significantly different compared to initial time $t_{0}$. 


\subsection{Effects of Acute Injection of Compound 1 on Blood Pressure and Heart Rate}

The injection of compound 1 in normotensive rats (NTR) resulted in a significant $\mathrm{P}<0.01$ rapid reduction of systolic blood pressure (SBP). As shown in fig. 7 compound 1 reduced the SBP in NTR by $17.03 \pm 2.79 \%$ and $38.04 \pm 0.07 \%$ $(\mathrm{P}<0.01)$ representing at the compound $1(100 \mu \mathrm{g} / \mathrm{kg})$ and compound $4(70 \mu \mathrm{g} / \mathrm{kg})$ respectively. The first and rapid hypotensive response was followed by a transient increase of systolic blood pressure, after that SBP decrease progressively and significantly $\mathrm{P}<0.01$ until the end of the observation period the SBP was at $38.04 \pm 2.24 \%$ at the compound 1 $(100 \mu \mathrm{g} / \mathrm{kg})$ and increase of $1.33 \pm 0.37 \%$ at the compound 5 $(100 \mu \mathrm{g} / \mathrm{kg})$. The injection of compound $4(70 \mu \mathrm{g} / \mathrm{kg})$ in NTR resulted in a significant $\mathrm{P}<0.01$ rapid increasing of heart rate by $17.52 \pm 0.4 \%$.

\subsection{Mechanisms of Hypotensive Effects of Eribroma oblongum Compound 1 in Anesthetized Normotensive Rats}

The pretreatment of normotensive rats with reserpine $(5 \mathrm{mg} / \mathrm{kg})$, NAME $(5 \mathrm{mg} / \mathrm{kg})$ after compound 1 , Propranolol (Prop) $(30 \mu \mathrm{g} / \mathrm{kg})$ and yohimbine (Yohim) $(100 \mu \mathrm{g} / \mathrm{kg})$ have significantly compared to initial time $t_{0}$ reduced the immediate hypotensive response of rats to compound 1 by $11.70 \pm 2.45 \%(\mathrm{P}<0.01), 10.28 \pm 4.77 \%(\mathrm{P}<0.05), 29.45 \pm 2.82 \%$ $(\mathrm{P}<0.01)$ and $21.30 \pm 1.88 \% \quad(\mathrm{P}<0.05)$ respectively. The pretreatment of normotensive rats with propranolol or NAME prior compound 1 antagonist have significantly $\mathrm{P}<0.05$, compared to compound 1 reduced the immediate hypotensive response of rats to compound 1 by 29.45 $\pm 2.89 \% ; 2.06 \pm 3.54 \%$. The later hypotensive response of extract after pretreatment with reserpine, propranolol or NAME prior compound 1 antagonist were significantly reduced by $6.17 \pm 6.15 \%(\mathrm{P}<0.01), 17.92 \pm 4.05(\mathrm{P}<0.05)$ and $4.09 \pm 1.54 \%(\mathrm{P}<0.05)$ respectively. NAME after compound 1 and all antagonists used was reduced significantly $\mathrm{P}<0.01$ compared to compound 1 without antagonist (fig. 8).
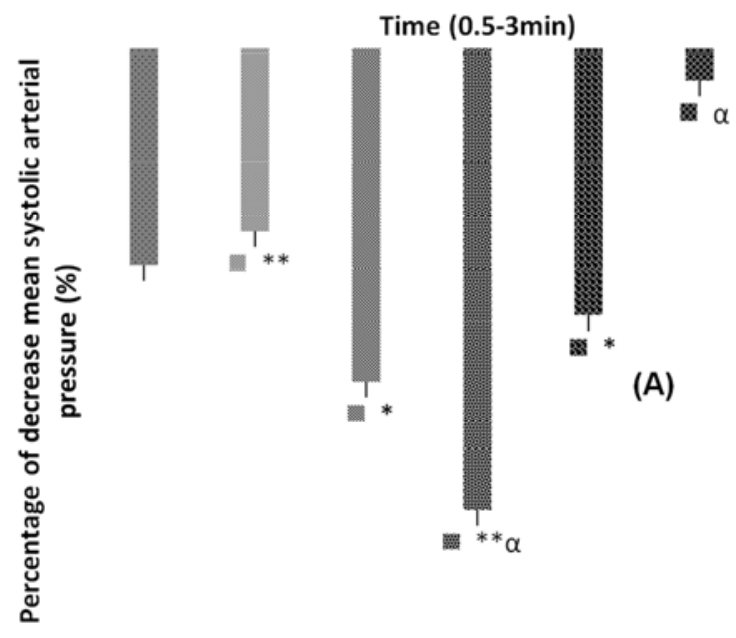

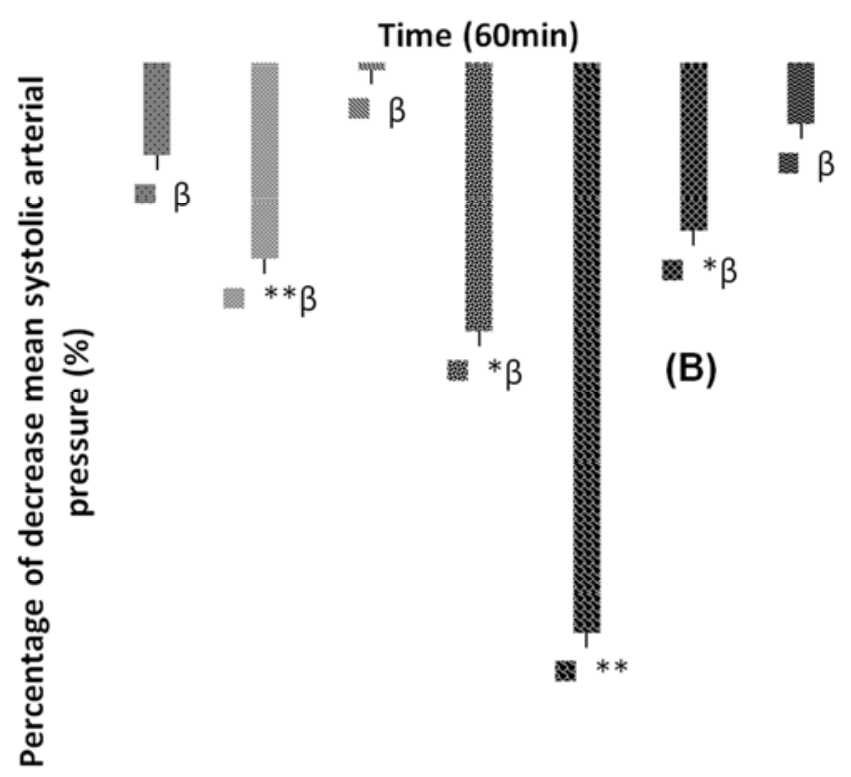

Figure 8. The maximal immediate changes(time 0.5-3min) (A) and later changes (time 60min) (B) in mean systolic arterial pressure in anesthetized animals that received intravenous injection of $F 1100 \mu \mathrm{g} / \mathrm{kg}(F 1=$ butilinic acid purified from Eribroma oblongum). Some animals received and additional pretreatment of Yoh.(Yohimbine $100 \mu \mathrm{g} / \mathrm{kg}$ ); Prop. (Propranolol $30 \mu \mathrm{g} / \mathrm{kg}$ ); Atro. (Atropine $1 \mathrm{mg} / \mathrm{kg}$ ); NAME (Nw-Nitro-L-Arginine Methyl Esther, $5 \mathrm{mg} / \mathrm{kg}$ ) an inhibitor of nitric oxide synthase 5 minutes prior and after the plant extract administration. Res. (Reserpine $5 \mathrm{mg} / \mathrm{kg}$ ) were admisnistered 3 days before the plant extract administration. $n=5$ each bar represents the means \pm SEM of group; ${ }^{*} P<0.05,{ }^{* *} P<0.01$; significantly different compared to initial time $t_{0}$ and ${ }^{\alpha} P<0.05,{ }^{\beta} P<0.01$; significantly different compared to $F 1$ without antagonisms.

\section{Discussion}

This study investigated the acute effects of the stem back ethyl acetate extract and the five pure compounds witch were isoled from it. The phytochemical screening of ethyl acetate extract was done as described by [13]. The result revealed the presence of reduced sugar, triterpene, terpenoids, flavonoids, phenols and saponins. Alkaloids, lipids, steroid cardiac glycosides, anthraquinones, and tannins were absent.

In our study ethyl acetate extract of Eribroma oblongum reduced the SBP at $5.76 \pm 0.86 \%, 8.48 \pm 3.47 \%$ respectively at the dose 10 and $20 \mathrm{mg} / \mathrm{kg}$ SBP at $38.04 \pm 3.17 \%$, $10.27 \pm 0.68 \%, 1.33 \pm 7.92 \%, 5.73 \pm 0.12 \%$ and $1.33 \pm 9.91 \%$. The compound $1(100 \mu \mathrm{g} / \mathrm{kg})$ was used to evaluate the mechanisms involved in the hypotensive effects of betillinic acid in normotensive rats.

During all this experimental study, we are revealed a great number of deaths of rats. The percentage of death was gradually higher by $40 \%, 70 \%$ and $80 \%$ at the dose 10,20 and $30 \mathrm{mg} / \mathrm{kg}$ respectively. Furthermore we have observed these similar results with the compound 4 or compound 5 which have presented $90 \%$ and $20 \%$ of death at the dose 70 and $100 \mu \mathrm{g} / \mathrm{kg}$ respectively. These results are correlated those obtained with to the phytochemical screening which revealed the present of triterpene and terpenoids. These toxicities results could been demonstrated in the work of [16], [17] 
which proved that the in vitro antitumor cytotoxic activity of BA has been illustrated in broad spectrum of cancer cell lines including those of leukemia, neuroblastoma, colon, breast, melanoma, lung, prostate, and cervical origin.

Six pure compounds were isolated from ethyl acetate fraction; only five of these compounds were investigated in this study. We have identified two of them: betulinic acid (3ß-hydroxy-lup-20(29)-en-28-oic acid) and tridecyl 9hydroxypentanoate, which is corresponded to compound 1 and compound 2. The compound 1 is a tritertenoid which activities was been demonstrated where as compound 2 is a fatty acid which activities was not been demonstrated now. For the remainder of this study, the fraction F1 is the pure compound 1 who presented the best activity than other.

Betulinic acid is an important natural product widely distributed throughout the plant kingdom [18]. Betulinic acid (BA) exhibits various biological activities, such as anti-HIV, anti-inflammatory, antioxidant, antiretroviral and antibacterial properties [19], [20].

The intravenous administration of ethyl acetate extract or compound 1, 2, 3 and 5 in normotensive anesthetized rats induced a blood pressure lowering effect accompanied by a reduction of heart rate. The hypotensive effect lasted 4 minutes when the heart rate was still significantly low. These results suggested that the hypotensive effect of the extract may be due to its bradycardiac effect. The fall in blood pressure induced by the extract might stimulate the baro-reflexes. Catecholamines are then released to cause a transient rise in pressure due to a vasoconstriction. As against the compound 4 after intravenous administration in normotensive anesthetized rats inducted a blood pressure significant $\mathrm{P}<0.01$ lowering effect accompanied by a significant $\mathrm{P}<0.01$ increasing of heart rate. The presence of triterpenes in the ethyl acetate extract or pure compound 1 account for its cardiovascular activity. This group of secondary plant metabolites widely occurring in the vegetable kingdom has been shown to display a remarkable array of biochemical and pharmacological actions, including cardiovascular effects [21].

L-NAME, a selective inhibitor of nitric oxide synthase induced 5 minutes prior the compound 1 significantly reduced $\mathrm{P}<0.05$ the immediate hypotensive effects of $\mathrm{BA}$. These resultat suggest that BA may act throw the endothelium-mediated/nitric oxide. However propranolol, (the beta blocker may oppose the vascular smooth muscle relaxation induced by the activation of the beta 2 receptor by endogenous epinephrine) appears to potentialize significantly $\mathrm{P}<0.05$ the immediate hypotensive effects of BA [22], [23]. The pretreatment of normotensive rats with reserpine $(5 \mathrm{mg} / \mathrm{kg})$, (inhibitor of vesicular storage of biogenic amines) were admisnistered 3 days before the plant extract administration, yohimbine, (a selective $\alpha_{2}$-adrenoceptor) antagonist, atropine, (the muscarinic receptor) antagonist and L-NAME induced 5 minutes after the compound 1 did not modify the immediate hypotensive effect of BA. At the later response, atropine sulfate, reserpine, propranolol or LNAME were partially blocked the hypotensive effects of BA. Whereas yohimbine, was completely blocked the hypotensive effect of extract. The resultats suggest that the $\alpha$ ${ }_{2}$ adrenoceptor system do not participate in hypotensive effect of BA. A dose used in this study $(0.1 \mathrm{mg} / \mathrm{kg})$, yohimbine can unlock the presynaptic alpha-2 adrenergic receptor. The effect of yohimbine has been studied in a small dose because high doses of yohimbine increased sympathetic tone and decreased vagal tone [24].

\section{Conclusion}

At the end of this study the result demonstrates that the hypotensive effects activity of the ethyl acetate extract of the stem bark of Eribroma oblongum (Malvaceae) lead to the phytochemical study of this extract which established Betulinic acid as the main hypotensive principle, its activity was 200 times more lofty as crude extract. The other compounds isolated: tridecyl 9- hydroxyloctadecanoate, a fatty acid and 3 compounds showed few activities. The structure of isolates was established on the basis of NMR inspection, mass spectrometric data and by comparison with those previously reported in the literature. Our data validate the use of the extract traditional medicine against hypertension.Further studies are from now evaluated the toxicity of Eribroma oblongum.

\section{Acknowledgements}

We wish to thank Pr DIMO Théophile Head of the Laboratory of Animal Physiology in the Department of Physiology, Faculty of Sciences, University of YaoundéCameroon the Laboratory of Organic Chemistry and Natural Product of Professor Ngadjui, Doctor Talla Emmanuel and the Animal House for preclinical toxicology studies of Professor Fokunang Charles.

\section{Competing Interests}

Authors have declared that no competing interests exist.

\section{References}

[1] Bullock J, Boyle J, Wang M B. Hypertension. In Physiology $3^{\text {rd }}$ edition. Williams and Wilkins publisher London, 1995; 189-190.

[2] Brownstein MJ, Stanlenhoef AF, Kwiterovich PO. Influence of vasoconstricting hormone in blood circulation. Journal of Clinical Investigation 1998; 102: 1041-1044.

[3] Bopda Mtopi, OS, Dimo T, Nguelefack TB, Dzeufiet Djomeni D, Rakotonirima SV, Kamtchouing P. Effect of Brillantaisia Nitens Lindau (acanthaceae) methylene choride/methanol leaf extract on rat arterial blood pressure and heart rate. Pharmacologyonline, 2007; 1: 495-510.

[4] Wilkie, Clarka, Penningtonr T, Cheekm P, Bayer C, Wilcock CC. Phylogenetic relationships within the subfamily Sterculioideae (Mal-vaceae/Sterculiaceae-Sterculieae) using the chloroplast gene ndhF. Systematic Botany, 2006; 31: 160170 . 
[5] Bolza E, Keating WG. African timbers - the properties, uses and characteristics of 700 species. C.S.I.R.O. Report division of Building Research, Melbourne, 1972.

[6] Carvajal-Zarrabal O, Barradas-Dermitz DM, Zaida OF, Hayward-Jones PM, Nolasco-Hipólito C, Aguilar-Uscanga MG, Miranda-Medina A, Bin Bujang K. Hibiscus sabdariffa $L$., roselle calyx, from ethnobotany to pharmacology. Journal of Experimental Pharmacology, 2012; 4: 25-39.

[7] Caluwé E, Halamová K, Van Damme P,. Adansonia digitata L. A review of traditional uses, phytochemistry and pharmacology. afrika focus, 2010; 23: 11-51.

[8] Mangambu MJD, Mushagalusa KF, Kadima NJ. Contribution á l'étude phytochimique de quelques plantes médicinales antidiabétiques de Bukavu, R. D Congo. Journal of Applied Biosciences, 2014; 75: 6211-6220.

[9] Hamack LK, Rydell SA, Stang J. Prevalence of use of herbal products by adults in the Minneapolis/St paul, Minn, metropolitan area. Mayoclin Proceedings 2001; 76 (7): 688694.

[10] Amic D, Amie DD, Beslo D, Trinajstic N. Structural-radical scavenging activity relationship of flavonoids Croatia Chemica Acta, 2003; 76: 55-61.

[11] Aqil F, Ahmad I, Mehmood Z. Antioxidant and free radical scavenging properties of twelve traditionally used. India medicinal plants. Turk J Biol, 2006; 30: 177-183.

[12] Khalafalla MM, Abdellatef E, Dafalla HM, Nassrallah AA, Aboul-Enein KM, Light foot DA, El-Deeb FE, El-shemy HA. Active principle from moringa oleifera Lam leaves effective against two leukemias and a hepatocarcinoma. Afr J Biotechnol, 2010; 9 (49): 8467-8471.

[13] Sumitra C, Jigna P, Nehal K. Evaluation of antibacterial activity and phytochemical analysis of Bauhinia variegate $\mathrm{L}$. bark. African Journal of Biomedicinal Research, 2006; 9: 5356.

[14] Dimo T, Nguelefack TB, Tan PV, Yenah MP, Dongo E, Rakotonirina SV, Kamany A, Bopelet M. Possible mechanisms of action of the neutral extract from Bidens plosa L. Leaves on the cardiovascular system of anaesthetized rats. Phytotherapy Research, 2003; 17: 1135-1139.

[15] Mahato S.B., Kundu A.P., ${ }^{13} C$ NMR spectra of pentacyclic triterpenoids. A compilation and some salient features. Phytochemistry 1994, 37, 1517-1575.

[16] Pisha E, Chai H, Lee IS, Chagwedera TE, Farnsworth NR, Cordell GA, Beecher CW, Fong HHS, Kinghom AD, Brown
DM, Wani MC, Wall ME, Hieken TJ, Gupto TKD \& Pezzuto JM. Discovery of betulinic acid as a selective inhibitor of human melanoma that functions by induction of apoptosis, Nat Med, 1995; 1: 1046.

[17] Chintharlapalli S, Papineni S, Lei P, Pathi S \& Safe S. Betulinc acid inhibits colon cancer cell and tumor growth and inducues proteasome dependent and -independent down and regulation of specificity proteins (SP) transcription factors, BMC cancer, 2011; 11: 371.

[18] Cichewicz RH and Kouzi SA. Chemistry, Biological Activity, and Chemotherapeutic Potential of Betulinic Acid for the Prevention and Treatment of Cancer and HIV Infection. Medicinal Research Reviews, 2004; 24 (1): 90-114.

[19] Fujioka T, Kashiwada Y, Kilkuskie RE, Cosentino LM, Ballas LM, Jiang JB, Janzen WP, Chen IS, Lee KH: Anti-aids agents, 11. Betulinic acid and Platanic acid as anti-HIV principles fromsyzigium claviflorum, and the anti-HIV activity of structurally related triterpenoids.j Nat prod, 1994; 57: 243247.

[20] Yogeeswari P, Sriram D: Betulinic acid and its derivatives: A review on their biological properties. Curr Med Chem, 2005; $12: 657-666$

[21] Zhang C, Kuroyangi M, Tan BK. Cardiovacular activity of 14deoxy-11, 12 didehydroandrographolide in the anaesthetised rat and isolated right atria. Pharmacological Research, 1998; 38: 413- 417.

[22] Tsague MV, Fokunang NC, Ngameni B, Tembe-fokunang EA, Guedje NM, Ngo Lemba Tom E, Atogho-Tiedeu B, Zintchem RF, Mecthi Dongmo M, Ngoupayo J, Sokeng S, Dzeufiet Djomeni, Oben JE, Dimo T, Ze Minkande J and Ngadjui Tchaleu B. Pre-clinical evaluation of the hypotensive and anti atherogenic activity of hydroethanolic extract of Eribroma oblongum (Malvaceae) stem bark on wistar rats models. British Journal of Pharmaceutical research. 2015; 5(1): 1-14.

[23] Tsague Marthe Valentine, Fokunang N. Charles, Tembe Achick Estella, Mvondo Anne Mauricette, Afane Ela Anatole, Oben E. Julius, Ngadjui Tchaleu Bonaventure, Ntchapda Fidele, Sokeng Dongmo Selestin, Nyangono Biyegue Christine Fernande, Dimo Theophile, Ze Minkande Jacqueline. Hydroethanolic Extract of Eribroma oblongum (Malvaceae) Stem Bark Prevents Hypertension, Oxidative Stress and Dyslipidemia in L-NAME Induced Hypertension in Wistar Rats. Journal of Diseases and Medicinal Plants. 2016 Vol. 2, No. 4, pp. 43-50.doi: 10.11648/j.jdmp.20160204.11

[24] Andréjak M, Ward M, Schmitt M. Cardiovascular effects of yohimbine in anasthetized dogs. European Journal of Pharmacology. 1983; 94: 219-228. 